\title{
Social capital in vulnerable urban settings: an analytical framework
}

\author{
Desire Mpanje, Pat Gibbons and Ronan McDermott ${ }^{*}$
}

\begin{abstract}
Social capital has been identified as crucial to the fostering of resilience in rapidly expanding cities of the Global South. The purpose of this article is to better understand the complexities of urban social interaction and how such interaction can constitute 'capital' in achieving urban resilience. A concept analysis was conducted to establish what constitutes social capital, its relevance to vulnerable urban settings and how it can be measured. Social capital is considered to be constituted of three forms of interaction: bonds, bridges and linkages. The characteristics of these forms of interaction may vary according to the social, political, cultural and economic diversity to be found within vulnerable urban settings. A framework is outlined to explore the complex nature of social capital in urban settings. On the basis of an illustrative case study, indicators are established to indicate how culturally specific indicators are required to measure social capital that are sensitive to multiple levels of analysis and the development of a multidimensional framework. The framework outlined ought to be adapted to context and validated by future research.
\end{abstract}

Keywords: Social capital, Concept analysis, Urbanisation, Urban vulnerability, Slums

\section{Introduction}

Urban areas can be rendered vulnerable due to multiple exacerbating factors such as rapid and unplanned development, environmental degradation, precarious livelihoods and resource pressures. These challenges are likely to grow given that the proportion of the world's population living in urban areas is projected to increase from the current $53 \%$ to a projected $70 \%$ by 2050 (IDMC \& NRC 2014; UNISDR 2014). Over the past 40 years, the urban population in lower income and fragile countries has increased by 326\% (UNISDR 2014). Approximately one billion people or one third of the developing world's urban population live in slums, mostly in highly vulnerable areas (UN-Habitat 2009; Lall and Deichmann 2012). Among displaced persons, more than half seek safety and opportunity in urban areas, often living alongside the urban poor and other migrants and exposed to the risk of abuse, exploitation and a range of hazards (Global CCCM Cluster 2014).

The 'typical' humanitarian crisis of the future is likely to be urban rather than rural with all the attendant

\footnotetext{
* Correspondence: ronan.mcdermott@ucd.ie

Centre for Humanitarian Action, School of Agriculture and Food Science, University College Dublin, Belfield Campus, Dublin 4, Ireland
}

systemic complexity that cities present (Apraxine et al. 2012; Pantuliano et al. 2012; Pavanello 2012; Parker and Maynard 2015; World Humanitarian Summit Secretariat 2015). This sentiment is echoed in a raft of recent global policy documents that warn of the future urban threat, including the Sendai Framework for Disaster Risk Reduction 2015-2030; Sustainable Development Goals (Murshed 2015); World Humanitarian Synthesis Report, October 2015 (World Humanitarian Summit Secretariat 2015); Secretary General's Report in preparation for the World Humanitarian Summit (UN General Assembly, 2016); UN-Habitat III, October 2016 (UN-Habitat 2016); and the IFRC World Disasters Report 2016 (IFRC 2016). Against this policy backdrop, there are calls to build urban resilience.

While the debate concerning the definition and practice of urban resilience ${ }^{1}$ continues, a growing number of academics and policymakers are suggesting that the solutions to humanitarian needs should come from within affected communities or what is being termed 'localised response' (Gingerich and Cohen 2015; Wall and Hedlund 2016). In this vein, the World Humanitarian Summit (WHS) consultations recommended that humanitarian aid organisations invest in building social 
capital and strengthening local structures (World Humanitarian Summit Secretariat 2015, p.57). Similarly, Gibbons et al. (2017, p.10) advise that recognising resources and capacities of beneficiaries requires close engagement and the building of a sense of empathy with affected populations that recognises their agency as they bid to recover and return to normality. However, urban contexts, especially in such places as informal settlements and slum areas, are extremely diverse and complex such that enhancing the absorptive, adaptive or transformative capacity requires a deep understanding of the social context. Contemporary approaches and strategies do not fully consider the community institutions and the relationships that shape the quality and quantity of social interactions in urban settings that ultimately impact on the lives and livelihoods of vulnerable urban dwellers (Concern Worldwide and USAID 2014). Such community institutions and relationships emerge and develop under conditions characterised by the increased transience of populations, greater communication possibilities, increased marketisation of relations and stark economic, and social and ethnic heterogeneity (Knox-Clarke and Ramalingam 2012). While a link between social capital and improved individual, household and community welfare in resource-poor settings has been identified, the contribution that social capital makes to resilience is still unclear (Aldrich 2012a, b; Story 2013; Béné et al. 2015; Aldrich and Smith 2015; Pfefferbaum et al. 2015; Béné et al. 2016).

The complexity and diversity of urban social systems combined with the recognition of increasing urban vulnerability provide an ideal testbed for exploring this relationship. Nevertheless, it is important to be cognisant that the measurement of social capital remains problematic. This is especially the case in informal urban settlements where aggregated data can mask stark inequalities within populations which in turn can undermine social capital (Concern Worldwide and USAID 2014). The adaptation and validation of approaches to measuring social capital at various levels of analysis, in particular in the multifaceted complexity of informal urban settlements, is thereby urgently warranted.

Within the current context in which the humanitarian sector has been exhorted to recalibrate their approaches to take into account the urban dimension, Aldrich and Smith (2015, p. 6) identify the need to guide the aid community concerning the form of social capital-bonding, bridging or linking - that should be emphasised according to the particularities of a variety of humanitarian settings. However, various research studies conducted in urban areas, in slums and in informal settlements on social capital do not adequately provide theoretical basis hence lacks sufficient presentation and use of social capital conceptual and analytical framework. Differentiating the forms of social capital is important given the emergence of literature that eschews the unmitigated celebration of social capital and highlights its potential dark side, arising from bonding social capital (Portes 1998, 2014). By exploring the complex nature of social capital in vulnerable urban settings, informed recommendations can be provided to the aid community to build on social capital in their programming.

This article by way of concept analysis advances the debate concerning the building of social capital in vulnerable urban areas, in particular the value of social capital in localising humanitarian response ${ }^{2}$ in slums and informal settlements. The aim is to develop a framework to exploit existing potential social capital that can enhance efforts to build resilience in vulnerable urban settings. Therefore, the objectives are twofold: (a) to establish what constitutes social capital, its relevance to vulnerable urban settings and how it can be measured and (b) to develop a multilevel and multidimensional framework to aid in exploring the complex nature of social capital in vulnerable urban settings. In pursuing this latter objective, an illustrative case study is presented that serves to demonstrate the operationalisation of a conceptual/theoretical framework of social capital in vulnerable urban settings. It does so by drawing on preliminary findings from a research project conducted in informal settlements in Nairobi.

\section{Research approach: concept analysis in humanitarian action}

Concept analysis as a research method is a process of determining the similarities and contrasts between concepts (Walker and Avant 1995, 2005, 2011; Gibbons 2017). In that manner, it helps to clarify and describe the concepts belonging to the whole, their characteristics and relations they hold within systems of concepts (Nuopponen 2010). The methods of Walker and Avant (1995, 2005, 2011) and Gibbons (2017) were used as the framework to guide the analysis. The steps involved in the concept analysis were as follows:

(1) The analysis of 'social capital' was conducted to clarify the meaning of the concept, to develop an operational definition and to distinguish the relevance of the concept in vulnerable urban contexts.

(2) The defining attributes of social capital were determined including the instrumental and emancipatory rationale for its application in urban settings.

(3) Appropriate indicators for the attributes of social capital were developed to establish a framework.

(4) An illustrative case of social capital that assigns appropriate and relevant indicators to the attributes 
in a context-specific vulnerable urban setting is presented.

Although social capital has become increasingly invoked in humanitarian discourse in recent times, the term has been in use for decades. Keeley (2007) indicates that the term 'social capital' may first have appeared in a book authored by Lyda Hanifanin published in 1916. The book discussed how neighbours could work together to oversee schools. The term was used to describe what counts in the daily lives of people: namely good will, fellowship, sympathy and social intercourse (Keeley 2007). Its understanding has evolved over these decades resulting in a rich body of literature on social capital. In its most generic sense, social capital can be defined as the 'networks of relationships among people who live and work in a particular society, enabling that society to function effectively' (Oxford English Dictionary, 2017 online). However, scholars who popularised the concept like Bourdieu, Coleman and Putnam emphasised social capital as a collective asset (Lin 1999a). Bourdieu's (1986) contribution concerned the size and strength of networks, while Coleman (1990) considered social capital as a resource that can be deployed by social actors and transformed into other forms of capital, including human capital. Putnam (1993, 2000), on the other hand, was interested in social organisations emphasising the importance of features including norms, trust and networks.

More recent definitions focus on the positive links, shared values and understanding of social interaction (Keeley 2007). For instance, Siegler (2014) contends that social capital brings about connections that generate benefits due to tolerance, solidarity and trust. Scrivens and Smith (2013) argue that the term social capital conveys the idea that human relations and norms of behaviour have instrumental value in improving different aspects of people's lives. Such aspects play a significant role in shaping individual as well as collective wellbeing outcomes. However, one should be cognisant that not all social interaction constitutes social capital. Portes $(1998,2014)$ notes how social interaction can result in 'social liabilities'. Typical examples of such social liabilities include organised crimes, nepotistic practices, social stratification and corruption that can arise from dense networks of social interaction.

In bringing together the disparate and rich understandings of social capital, the study recognises both the quantity and quality of the social interactions, the varying levels of such social interaction (individual, community and locality) and the value of the interaction in achieving individual and collective goals.

Moreover, the urban ${ }^{3}$ setting provides a particular type of locality typified by high population density, higher mobility and high interdependency as compared to the self-sufficiency of the rural. The population in vulnerable urban settings, especially in informal settings and slums, rely on each other to fulfil basic needs and access services. There is greater interdependence on existing infrastructure, social, political and economic systems, e.g. access to water, security, and microfinance (Parker and Maynard 2015). In rural areas, the households and population may be self-dependent as long as they are food secure and have disposable income.

Social relations may be more instrumental in urban settings than tangential towards achieving basic needs. This leads us to an interesting question of what social capital means in vulnerable urban environments. Therefore, by combining significant contributions on the meaning of social capital and the urban, the authors propose that social capital in vulnerable urban contexts can be understood as:

'the institutions and relationships that shape the quality and quantity of social interactions in vulnerable urban settings, which in the end enhance individual, community and society's capacity to collaborate in the achievement of both individual and collective aims before, during and after a humanitarian crisis.'

\section{Understanding the concept and its relevance in complex urban settings}

Walker and Avant $(1995,2011)$ indicated that establishing the defining attributes of the concept under analysis is the most critical part of concept analysis research. The process of defining attributes involves examining the clusters of elements associated with the concept. Therefore, the starting point to analysing attributes of social capital is to examine the relationships that shape the quality and quantity of social interaction that is relevant and appropriate in vulnerable contexts. The literature identifies that such relationships are embedded in three forms of social capital: bonding, bridging and linking capitals (Lin 1999b; Narayan 1999; Dasgupta and Ismail 1999; Lofors and Sundquist 2007; Keeley 2007; Ledogar and Fleming 2008; Hawkins and Maurer 2010; Álvarez and Romaní 2017).

\section{Bonding (social) capital}

Bonding capital refers to personal relations that are based on a sense of collective identity such as family, close friendship and the sharing of the same culture or ethnicity. Siegler (2014) considers it to be concerned with whom people know and what they do to establish and maintain their personal relationships. Therefore, it concerns the quality, structure and nature of people's relationships (Scrivens and Smith 2013). These relations influence physical and mental health, economic wellbeing and life satisfaction. Such factors are what Lin 
(1999a) argued to be the outcomes or in other words the returns of social capital due to expressive actions. Furthermore, the urban poor in the developing world relies heavily on bonding capital to help them 'get ahead' (Woolcock 1998, 2005). It is not self-evident to the outsider that such reliance would remain the same in the situation of extreme vulnerability arising due to humanmade or natural hazards. The next three sections present the attributes of bonding capital. These attributes are the quantity of relationships (structure and nature), the quality of relationships (norms of trust and reciprocity) and the degree of social influence in vulnerable urban settings.

\section{Quantity of relationships (structure and nature of relationships)}

The nature of relationships mainly refers to the structure and strength of the connections among and between individuals. Social fabric is made up of a network of individuals or groups connected by one or more specific types of interdependency, such as friendship, kinship, common interest, financial exchange, sexual relationships or relationships of beliefs, knowledge or prestige (Wasserman and Faust 1994; Freeman 2004). In drawing on the social network ${ }^{4}$ analysis (SNA) technique, one can assess the 'quantity' or frequency of the social relationships (interdependence) in terms of both-ego-centric analysis, ${ }^{5}$ also referred to as personal network analysis, and socio-metric analysis or whole network analysis $^{6}$ (Freeman 2004; Rice and Yoshioka-Maxwell 2015). Fay (2005) indicates that social networks are less stable in urban areas, with relationships more likely to be based on the quality of reciprocal links between and among individuals and friends than on familial obligations. Understanding the value and stability of social networks in the urban context will contribute to the much-needed knowledge required to realise and enhance the localisation of humanitarian response. It will, therefore, be interesting in this study to find out how slum dwellers use social networks (connections and interdependencies) to enhance preparedness and resilience.

\section{Quality of relationships (norms of trust and reciprocity)}

Putnam (2000) and Stone (2001) indicate that bonding social capital involves trust and reciprocity in closed networks and helps the process of 'getting by' in life on a daily basis. Siegler (2014) argues that the quality of relationships (trust and values) that are beneficial for society, and therefore constitute capital, can determine how much people in society are willing to cooperate with one another. Also, through social influence, people obtain normative and informative guidance by relating their behaviour to others within the same group or among different groups (Coleman et al. 1957). The terms normative and informative guidance are used neutrally due to the capacity of bonding capital to lend itself towards negative as well as positive outcomes (Scrivens and Smith 2013).

Sako (1992: 69) defines trust as 'a state of mind an expectation held by one trading partner about another that the other behaves or responds in a predictable and mutually expected manner'. Trust is achieved when there is both commitment and intimacy (Drew et al. 2012), in the social interaction irrespective of the context or domain over which it is conferred (Kramer and Tyler 1996; Hardin 2002; Nooteboom 2002). Literature identifies three types of trust (Cook 2001; Smith 2010; Paliszkiewicz 2011), namely, (a) generalised trust, a kind of trust that is based largely on social learning and developmental processes; (b) particularised trust, the idea that people 'like me' can be trusted, but that other groups may not share my moral values; and (c) strategic trust, the idea that specific others have the appropriate motives and intentions in the belief that significant others can be relied upon to act in one's interests in specific situations and around specific issues. Stone (2001) likened strategic trust to public trust. An example of this kind of trust is the trust in the institution, the belief that police officers have appropriate motives towards citizens and are technically competent to protect citizens (Jackson et al. 2011, p. 270). Klinenberg (2002; as cited in Woolcock 2005) contends that even the most isolated individuals are better off if they happen to live in communities with high levels of trust and participation. The World Bank (2003) indicates that in poor urban areas, social fragility due to high ethnic diversity and profound economic inequality creates lowlevel generalised trust. The relative importance of these three types of trust (generalised, particularised and strategic) needs further investigation within vulnerable urban contexts, notwithstanding that indicator of trust may manifest itself differently across cultures (Keeley 2007).

On the other hand, reciprocity includes the processes of exchange within a relationship whereby there is an expectation of repayment of 'goods and services' provided (Stone 2001, p.30). She further argues that reciprocal relations are governed by norms, such that parties to the exchange understand the social contract they have entered and therefore their obligations. Based on the study findings of Robert (1973) conducted in Guatemala City, Woolcock (2005) reports that relationships in urban slums were forged by the quality of reciprocal links between individuals and friends other than familial obligations. Siegler (2014) indicates that the support received may be reciprocated with a different resource, e.g. one might receive emotional, practical or financial assistance, advice and guidance in return for unpaid work (or informal 
volunteering). Nevertheless, the extent to which such reciprocal links and the effect or influence of in times of stress in vulnerable urban contexts requires further investigation.

\section{Bridging (social) capital}

Bridging capital concerns the peoples' relations or links that stretch beyond a shared sense of identity, for example to distant friends, colleagues and associates. Drawing on Lin (1999a), it can be argued that bridges give rise to instrumental actions with three possible outcomes. These outcomes include economic (material resources such as wealth), political and social. Kreuter and Lezin (2002) argue that bridging social capital is comparable to institutional infrastructure; therefore, it should be detected at the organisational level, where norms, values and social structures facilitate more macroconnections. These values could be formal or informal and well-articulated. Bridging capital, as opposed to bonding capital, is about 'getting ahead', involving multiple networks which may make resources and opportunities which exist in one network accessible to a member of another network or locality (Stone 2001; Woolcock 2005). Furthermore, Woolcock (2005) argue that the urban poor in the developing world rely heavily on their friends and relatives to help them 'get ahead'. However, it is not clear whether such reliance remains the same in a situation of vulnerable urban contexts that are characterised by high mobility and greater interdependencies.

\section{Quality and quantity of meso-level connections}

Bridging capital facilitates collective action, civic engagement or citizen participation. Such actions and behaviours contribute positively to the collective life of a locality, community or society (Scrivens and Smith 2013; Siegler 2014). Civic engagement includes activities such as volunteering, political participation and other forms of community actions (Grootaert and Bastelaer 2001; Siegler 2014). Evaluation of bridging capital requires examination of such aspects of community governance and decision making, identification of community institutions, characterisation of community-institutional relationship and assessment of institutional networks and organisational density (Krishna and Shrader 1999, 2000). This means that bridging capital is mainly assessed at the meso level to achieve a more focused observation of local institutions, collective actions and civic engagement (Grootaert and Bastelaer 2001; Scrivens and Smith 2013; Siegler 2014).

The literature on measurement of bridging social capital in institutions, especially local associations, includes the examination of their internal heterogeneity and their wider networks, including their horizontal ${ }^{7}$ and vertical connections. Examining heterogeneity entails assessing the differences that exist between and among members of a locality/institution regarding gender, religion, ethnicity, wealthy and age (Grootaert and Bastelaer 2001; Stone 2001). Socio-structural issues might include organisational density and related characteristics, networks and mutual support mechanisms, exclusion or engagement barriers, collective action including formal and informal groups and conflict resolution systems. For example, Grootaert (1999), through his study of social capital, household welfare and poverty in Indonesia, found that greater heterogeneity of local associations (along with factors such as education, occupation and economic status) confers the greatest benefits of sharing information and knowledge. However, the effect of homogeneity and heterogeneity on the quality of social relations would also be useful in understanding the impact of bridging social capital on addressing urban vulnerabilities in informal settlements. For example, in the aftermath of the 1995 earthquake in Kobe, Japan, community groups in long-established areas of the city were shifted to temporary shelters. Shaw and Goda (2004) argue that such movement had a negative impact on community links, thereby hampering the rebuilding interpersonal relationships. It follows that it would be very interesting to determine how community links are developed and used in vulnerable urban settings.

\section{Linking (social) capital}

Linking capital concerns relations of individuals and communities with societal institutions-links to people or groups further up or lower down the social ladder (Keeley, 2007, p.102). Linking social capital is used to define relations that are characterised by power differences, the accumulation of ties with individuals in power and institutions of influence (Titeca and Vervisch 2008; Manzano Nunez 2016).

These linkages can be viewed to be hierarchical and reflect power, wealth and social status. Linking mainly refers to connections between individuals and groups in a community and formal institutions and systems such as education, governance and the economy. It involves social relations with those in authority, often the type of capital used to garner resources or power (Stone 2001). Musinguzi et al. (2017), in a research conducted in Uganda on the ability of Village Health Teams to link and connect communities with formal health care, premised their study on three assumptions that serve to outline in greater detail the nature and utility of such relations. Firstly, they argued that linking social capital assumes that networks do exist that connect vulnerable populations with those in power, that the people should have the capacity to engage in vertical connections to access resources and, finally, that the means of 
engagement facilitates and promotes linking social capital (ibid). It has also been argued that the connections between survivors and national and international nongovernmental organisations (NGOs) can play a vital role in helping to secure necessities and broader community recovery (Aldrich 2012b p. 173; Hawkins and Maurer 2010). Again, assessing vertical connections between vulnerable populations and those in power would also help to identify the impact of expectations the affected population may have during preparedness for, response to and recovery from disasters. Different typologies around expectations of response to the disaster can affect recovery processes as demonstrated by Chamlee-Wright and Storr (2010), which drew on a case of rebuilding processes by communities in New Orleans in the aftermath of Hurricane Katrina. Linking capital describes the amount of trust between individuals and societal institutions, in our case vulnerable urban societies (Sundquist et al. 2014). The importance of trust in addressing vulnerability to disasters has been highlighted in the literature relating to the disaster. Reinhardt (2015), who examined the political drivers of post-disaster resettlement in post-Katrina New Orleans, found that survivors exhibited less trust in public officials to manage disasters than those who were not affected.

\section{Quality and structure of linkages and institutions}

North (1990) states that institutions and organisations are different but related terms. Institutions comprise of rules, norms of behaviour, conventions and values that bind individuals together, structures that humans impose on their dealings with each other. On the other hand, organisations consist of groups of individuals engaged in a purposive activity (North 1990, 1992). Institutions are frequently viewed by sector such as the economic, social and political environments that shape the social structure (Grootaert and Bastelaer 2001). Such institutions encompass informal [local and horizontal] and formal [hierarchical and vertical] associations and relationships. Societal, institutional structures (organisations) include education, health services, the economy, and political and juridical sectors. Institutional relationships include macro-level governance, political regime, the rule of law, the court system and civil and political liberties [as part of quality]. Adger (2003) argues that the relations between actors and institutions play a significant role in shaping people's ability to act when collectively adapting to and recovering from natural disasters. Situations of humanitarian crisis require greater openness of institutions to engage with individuals or organisations. An understanding of the existing institutions and organisations and the linkages with individuals in vulnerable urban settings would then provide an opportunity for both national and international aid organisations to engage better with the affected population. Therefore, analysing linking capital in vulnerable urban settings would aid in obtaining not only a better understanding of the existing institutions and organisations but also the amount of trust people may have in these institutions and the access to the services (e.g. jobs, microfinance, education and justice) they provide in vulnerable urban settings.

\section{Study framework and selection of indicators for vulnerable urban contexts}

Scholars agree that obtaining a single or universal means of measuring social capital at local, national or international level is still challenging (Gallaher et al. 2013; Siegler 2014; Babcicky and Seebauer 2016). This is due to a number of reasons, including the following: (a) most of the definitions highlight that social capital is a multidimensional concept with different levels of analysis, (b) the nature and form of social capital changes over time, (c) the application of the concept is still essentially in its infancy (Keeley 2007) and (d) a wide range of approaches are taken in defining and measuring social $\mathrm{capital}^{8}$ (Gallaher et al. 2013; Siegler 2014). Critics also argue that the term social capital is vague, hard to measure and poorly defined while others challenge whether it can be considered a form of capital at all (ibid.). Against this backdrop, the authors argue that it is even more challenging to try to measure social capital in vulnerable urban contexts such as slums and informal settlements exposed to a wide range of disasters (including those arising from urban violence, natural hazards and extreme poverty) without a welldefined framework.

Woolcock and Narayan (2000) focused on measuring membership in informal and formal associations and networks. They examined formal group functioning, contributions to groups, participation in decision making and heterogeneity of membership, interpersonal trust and changes over time. Stone (2001) proposes focusing on the structure of social relations (network types, structure and systems) and quality of social ties (norms of trust and reciprocity). Grootaert and Bastelaer (2001), while interested in the issue of economic development, ${ }^{9}$ recommended focusing on the structural (local and societal institutions) and the cognitive dimensions (norms, trust and governance at a higher level) of social capital. More recent studies measure social capital as it relates to economic well-being (Scrivens and Smith 2013 ${ }^{10}$; Siegler 2014, 2015). Scrivens and Smith proposed a twoby-two measurement framework with two levels of analysis, individual and collective. Siegler (2014) used the same measure to assess how social capital contributes to the well-being of the people in the United Kingdom (UK). 
This study proposes the designing of the broader framework based on the understanding of social capital forms as bonds, bridges and linkages as they relate to urban slums. Nevertheless, both qualitative and quantitative indicators need to be developed according to the relevant vulnerable urban setting so that there is an inductive construction of indicators (Béné et al. 2012; Mitchell 2013). Such an approach would enable the establishment of context-specific indicators on the basis of culturally informed indicators that give meaning to the contribution of social capital to the provision of basic needs across several universal domains such as water, food, education, security and health in vulnerable urban settings.

Understanding how to measure social capital in slum areas of for example Jakarta, Bogotá and Nairobi for effective humanitarian action does require focusing on not only cognitive or collective actions but also structural factors such as macro-level governance and the quality of institutions. Figure 1 demonstrates this multilevel and multidimensional conceptualisation of the nature of social capital. The figure shows that social capital ranges from the cognitive to the structural and the micro to the macro as defined by Grootaert and Bastelaer (2001) while depicting the multidimensional factors as argued by Stone (2001). It also ranges from the individual, through collective, to the societal level, reflecting the multilevel nature of the concept (Scrivens and Smith 2013; Siegler 2014). Such an approach will help to understand how in a particular historical, cultural, political and economic context (Woolcock 2005), bonds, bridges and linkages are used for greater preparedness and enhancing resilience to address urban vulnerabilities.

\section{An illustrative case of measuring social capital in vulnerable urban contexts: Concern Worldwide's engagement in Nairobi, Kenya}

The purpose of the case study is to illustrate the operationalisation of a conceptual/theoretical framework in diverse, vulnerable urban settings. As indicated in the research approach section, concept analysis research method requires that a case should assign appropriate and relevant indicators to give meaning to the attributes of the concept under study, in this case, social capital in vulnerable urban settings. This case, therefore, illustrates the attributes of social capital set out in this paper by drawing on preliminary findings from a research project being conducted in informal settlements in Nairobi. While not setting out to measure social capital per se, the Indicator Development for Surveillance of Urban Emergencies ${ }^{11}$ (IDSUE) study provides some guidance as to the indicators of social capital in urban slums-especially about vulnerability. The IDSUE study has responded to the need for more disaggregated data in informal urban settlements that would allow for the identification of the threshold whereby chronic poverty tips into an urban emergency. Conducted in slums and informal urban settlements of Nairobi from 2012 to 2015, the study involved a baseline study and subsequent quarterly surveillance ${ }^{12}$ rounds. Approximately 30,000 households were surveyed. In all the surveys and rounds of surveillance, quantitative data were collected about household livelihoods, household income and expenditure, shocks and coping strategies. This illustrative case is based on the quantitative baseline data that was collected in Nairobi in the year $2015(n=1153)$ in the slums of Kibera, Kawangware and Eastleigh.

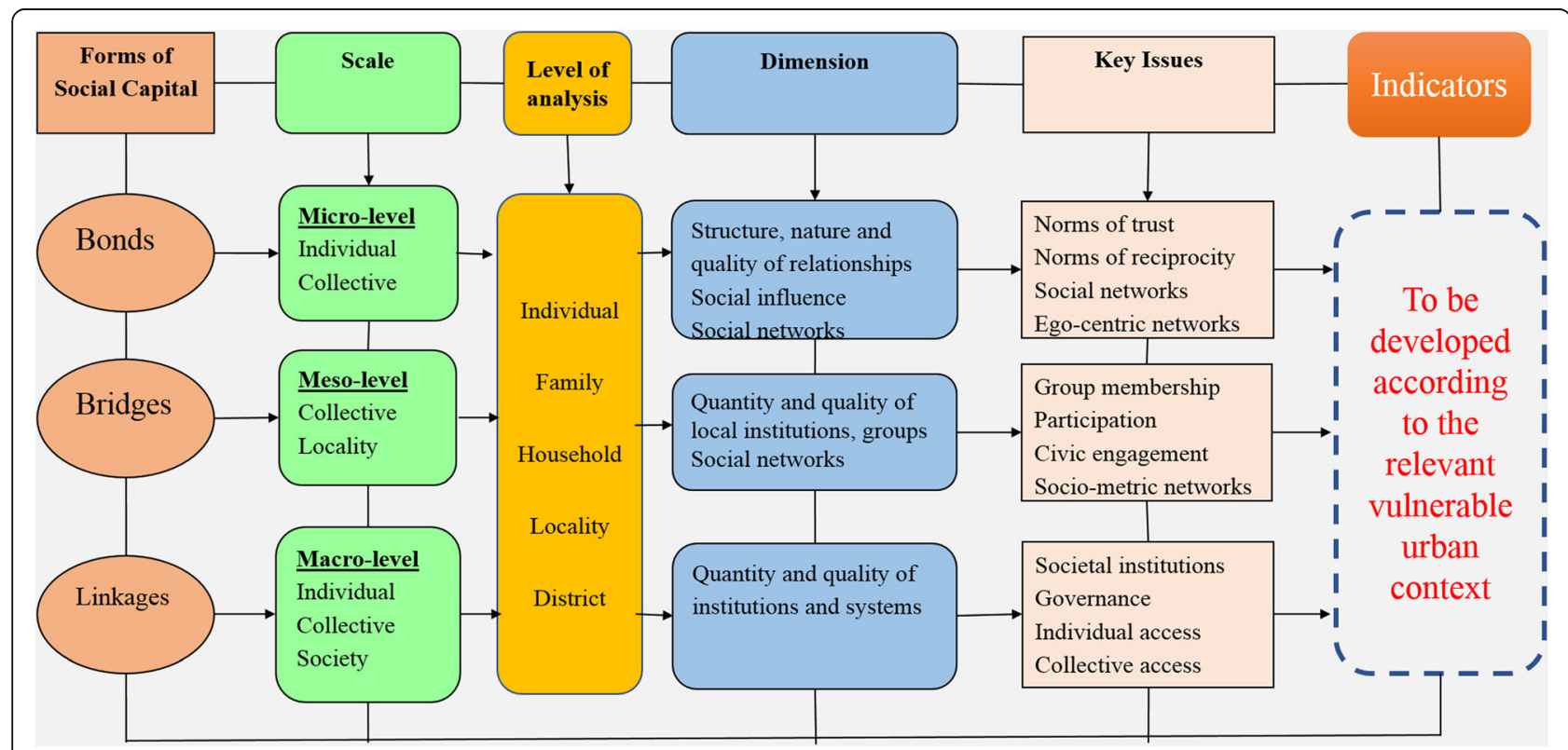

Fig. 1 Proposed social capital measurement framework to be adapted per social, political, economic and cultural context 


\section{The livelihood context}

Estimates of the population size of Nairobi's informal settlements are highly contested. Kibera, which in 2009 had a population size of about 170,000 people, ${ }^{13}$ is one of the biggest slums and 'informal economies' in Africa. ${ }^{14}$ Kawangware, a densely populated, impoverished informal settlement in eastern Nairobi, has a population size of around 150,000 to 200,000 people. On the other hand, Eastleigh, regarded as the second largest slum in Kenya, had a population size of about 174,000 in 2012 according to UNHCR. ${ }^{15}$ In the slums, daily labour and street hawkers (casual and temporary, e.g. dumpsites for scavenging) are part of the livelihood opportunities. The use of negative coping strategies is part of survival mechanisms in most of the slums. Housing and decent accommodation are common problems. The complexity of land ownership and security plays a significant role in slum development and the possibilities for upgrading the provision of essential services. Constant threats of eviction by landowners means that residents, NGOs and government are hesitant to improve or provide services to most of the slums. Water supply by the city authorities is not adequately available or at least expensive. Solid waste management (household, medical, other waste), drainage and excreta disposal (toilet facilities) remains a challenge.

Preliminary findings have shown us that quantitative indicators, where appropriately adapted to context, can provide insights into aspects of the social capital framework. The indicators are captured based on bonding, bridging and linking capital gleaned from IDSUE in the Nairobi survey.

\section{Bonding capital}

Applying the framework set out in Table 1, several indicators of bonding capital are identified in Table 2.

More than half of the residents (67\%) in the slums rely on only one breadwinner ${ }^{16}$ to provide for the needs of the household. The household size ranges from three members to more than 12 members. This indicates how strong ties are required for the survival of the families. Relations such as brother, brother-in-law, sister, sisterin-law and cousins were evident in the survey, which indicate that the residents tend to rely on extended families to survive. At the time of the survey, $50.5 \%$ of the households reported having a member of the household who was sick in the last 2 weeks. The majority of those who fell sick relied on close friends and family members for care and support.

Though only $17 \%$ of the households indicated to have removed a child from school, this is significant regarding bonding capital as the children may have been withdrawn either because of lack of support or because the child has to help in obtaining food or money to support the family. More than half of the respondents (56\%) reported being worried about food when asked to rate their distress about adjustment in food consumption they may have to make due to food insecurity. Even though some of the residents indicated they would never worry about spending a day or night hungry, those worrying about eating smaller or fewer meals, unwanted food and limited variety of food were in the majority. This shows the limited existence of social capital as people with high social support should be able to use

Table 1 Proposed social capital analytical framework (from theory to measurement)

\begin{tabular}{|c|c|c|c|c|}
\hline Form of social capital & Dimension & Key issues & & Measurement mechanism \\
\hline \multirow[t]{2}{*}{$\begin{array}{l}\text { Bonding capital (micro } \\
\text { and cognitive level) }\end{array}$} & \multirow[t]{2}{*}{ Personal relationships } & Quality of relationships & $\begin{array}{l}\text { Norms of trust (particularised } \\
\text { trust among familiars, generalised } \\
\text { trust of strangers, strategic trust, } \\
\text { civic/institutional trust) } \\
\text { Norms of reciprocity }\end{array}$ & \multirow[t]{2}{*}{$\begin{array}{l}\text { Household social (baseline) } \\
\text { surveys based responses } \\
\text { Ego-centric network analysis }\end{array}$} \\
\hline & & $\begin{array}{l}\text { Structure and nature of } \\
\text { relationships }\end{array}$ & $\begin{array}{l}\text { Social networks (types, size, spatial, } \\
\text { structural, relational) }\end{array}$ & \\
\hline \multirow[t]{2}{*}{$\begin{array}{l}\text { Bridging capital (meso } \\
\text { and structural level) }\end{array}$} & \multirow[t]{2}{*}{$\begin{array}{l}\text { Groups, organisations } \\
\text { and local institutions }\end{array}$} & $\begin{array}{l}\text { Quality of local groups } \\
\text { and institutions }\end{array}$ & $\begin{array}{l}\text { Group membership, participation } \\
\text { Rules and regulations } \\
\text { Collective actions } \\
\text { Civic and political engagement }\end{array}$ & \multirow{2}{*}{$\begin{array}{l}\text { Local institutions, organisations } \\
\text { and community profile (SCAT) } \\
\text { Socio-metric network analysis } \\
\text { Qualitative (phenomenological } \\
\text { and ethnographic) studies }\end{array}$} \\
\hline & & $\begin{array}{l}\text { Structure and nature } \\
\text { of local groups and } \\
\text { institutions }\end{array}$ & $\begin{array}{l}\text { Homogeneous, heterogeneous } \\
\text { Capacity and size }\end{array}$ & \\
\hline \multirow[t]{3}{*}{$\begin{array}{l}\text { Linking capital } \\
\text { (macro and structural level) }\end{array}$} & \multirow{3}{*}{$\begin{array}{l}\text { Societal institutions } \\
\text { and organisations } \\
\text { Societal processes }\end{array}$} & \multirow{3}{*}{$\begin{array}{l}\text { Existence of institutions } \\
\text { Quality of and access to } \\
\text { services }\end{array}$} & $\begin{array}{l}\text { Education, political, justice systems } \\
\text { Civic and political engagement }\end{array}$ & \multirow{3}{*}{$\begin{array}{l}\text { Aggregated survey based } \\
\text { responses. } \\
\text { Qualitative (phenomenological } \\
\text { and ethnographic) studies }\end{array}$} \\
\hline & & & $\begin{array}{l}\text { Governance, laws, policies, } \\
\text { approaches and strategies }\end{array}$ & \\
\hline & & & $\begin{array}{l}\text { Individual and collective access } \\
\text { to services and resources }\end{array}$ & \\
\hline
\end{tabular}


Table 2 Attributes of bonding capital in vulnerable urban contexts

\begin{tabular}{|c|c|c|c|}
\hline Form of social capital & Dimension & Key issues & $\begin{array}{l}\text { Indicators (in vulnerable urban } \\
\text { contexts_-slums and informal settlements) }\end{array}$ \\
\hline \multirow[t]{3}{*}{$\begin{array}{l}\text { Bonding capital (micro and } \\
\text { cognitive level) }\end{array}$} & $\begin{array}{l}\text { Personal relationships } \\
\text { (quality of relationships } \\
\text { structure and nature of } \\
\text { relationships) }\end{array}$ & $\begin{array}{l}\text { Norms of trust (particularised } \\
\text { trust among familiars, generalised } \\
\text { trust of strangers, strategic trust, } \\
\text { civic/institutional trust) } \\
\text { Norms of reciprocity }\end{array}$ & $\begin{array}{l}\text { Proportion of households relying on } \\
\text { others for help (e.g. for treatment, } \\
\text { care and support) } \\
\text { Proportion of individuals who } \\
\text { believe in the ability of others } \\
\text { (e.g. breadwinners and other income } \\
\text { earners) } \\
\text { Proportion of individuals who provided } \\
\text { and received support (e.g. sharing } \\
\text { food, remittances) } \\
\text { Proportion of individuals or households } \\
\text { relying on assets as a coping strategy } \\
\text { Proportion of individuals purchasing } \\
\text { food on credit as a coping strategy } \\
\text { Proportion of households worrying } \\
\text { about food }\end{array}$ \\
\hline & & $\begin{array}{l}\text { Social networks (types, size, } \\
\text { spatial, structural, relational) }\end{array}$ & $\begin{array}{l}\text { Centrality (degree, betweenness, } \\
\text { closeness) perceived importance } \\
\text { of individuals } \\
\text { Distance, i.e. connectedness of } \\
\text { individuals } \\
\text { Attributes of networks } \\
\text { (e.g. successfulness and attractiveness) }\end{array}$ \\
\hline & $\begin{array}{l}\text { Social influence } \\
\text { (conformity obedience } \\
\text { compliance) }\end{array}$ & $\begin{array}{l}\text { Normative (change to fit in a } \\
\text { group-to be liked or accepted) } \\
\text { Informational (change because } \\
\text { of desire to be correct, belief that } \\
\text { others have right information) }\end{array}$ & $\begin{array}{l}\text { Proportion of individuals who changed } \\
\text { thoughts, attitudes, feelings and } \\
\text { behaviour because of interaction with } \\
\text { others; doing things for others with a } \\
\text { choice to deny; doing things for others } \\
\text { without an opportunity to refuse }\end{array}$ \\
\hline
\end{tabular}

their ties and cope with distressful moments. Regarding coping strategies, the most frequently observed coping strategy among inhabitants of the slums of Eastleigh, Kawangware and Kibera was the purchase of food on credit-36.4\%. The second most commonly resorted to coping strategy was found to be asking for support from neighbours or relatives $(28.8 \%)$ and removing children from school. This indicates that a high proportion of vulnerable urban dwellers relied on people familiar to themselves for help and support in times of need. However, several other aspects of bonding capital need to be further explored in vulnerable urban contexts as per the framework, for example, the implication of network size on coping strategies and food security.

\section{Bridging capital}

The indicators detailed in Table 3 were found to be relevant for bridging capital.
The findings indicate at least some of the surveyed slum dwellers participate in local initiatives and are members of merry-go-round associations. Nonetheless, the influence or the impact of the internal heterogeneity and decision-making mechanisms of such organisations are not clear. Also, the proportion of slum dwellers who participate in social clubs, youth groups, political parties and other local institution is not apparent. Further exploration of bridging capital in vulnerable urban contexts is required.

\section{Linking capital}

Applying the framework set out in Table 1, the indicators of linking capital detailed in Table 4 were evident.

Concern Worldwide, through the IDSUE study and other programmes they have been implementing in the slums, have managed to establish partnerships and linkages with key stakeholders. The international organisation managed to establish links with Kenya Red Cross

Table 3 Attributes of bridging capital in vulnerable urban contexts

\begin{tabular}{|c|c|c|c|}
\hline Form of social capital & Dimension & Key issues & $\begin{array}{l}\text { Indicators (in vulnerable urban } \\
\text { contexts_-slums and informal settlements) }\end{array}$ \\
\hline $\begin{array}{l}\text { Bridging capital } \\
\text { (meso and structural level) }\end{array}$ & $\begin{array}{l}\text { Groups, organisations and local } \\
\text { institutions (quality of local } \\
\text { groups and institutions) }\end{array}$ & $\begin{array}{l}\text { Group membership, participation } \\
\text { Rules and regulations } \\
\text { Collective actions } \\
\text { Civic and political engagement }\end{array}$ & $\begin{array}{l}\text { Participation in political parties, social clubs, } \\
\text { associations, youth groups, voluntary } \\
\text { activities, e.g. voting } \\
\text { Decision-making mechanisms }\end{array}$ \\
\hline
\end{tabular}


Table 4 Attributes of linking capital in vulnerable urban contexts

\begin{tabular}{|c|c|c|c|}
\hline Form of social capital & Dimension & Key issues & $\begin{array}{l}\text { Indicators (in vulnerable urban } \\
\text { contexts_-slums and informal settlements) }\end{array}$ \\
\hline \multirow[t]{3}{*}{ Linking capital (macro level) } & \multirow[t]{3}{*}{$\begin{array}{l}\text { Societal institutions and organisations } \\
\text { Societal processes (existence of } \\
\text { institutions, quality of and access } \\
\text { to services) }\end{array}$} & $\begin{array}{l}\text { Education, political, justice systems } \\
\text { Civic and political engagement }\end{array}$ & $\begin{array}{l}\text { Existence of microfinance institutions, } \\
\text { education, health, security, market, } \\
\text { religious institutions } \\
\text { Proportion of people who votes } \\
\text { in elections }\end{array}$ \\
\hline & & $\begin{array}{l}\text { Governance, laws, policies, } \\
\text { approaches and strategies }\end{array}$ & $\begin{array}{l}\text { Rules, regulations, policies, laws } \\
\text { Partnerships and networks between } \\
\text { individuals and communities with } \\
\text { those (individuals and institutions) } \\
\text { with power, resources and influence }\end{array}$ \\
\hline & & $\begin{array}{l}\text { Individual and collective access } \\
\text { to services and resources }\end{array}$ & $\begin{array}{l}\text { Proportion of individuals with stable } \\
\text { source of livelihood (e.g. regular } \\
\text { monthly income, stable business) } \\
\text { Proportion of individuals with access } \\
\text { to education }\end{array}$ \\
\hline
\end{tabular}

Society (KRCS) and World Vision Kenya among others. However, the partnerships and networks of slum residents with national and international organisations need further exploration. Also, linkages between individuals and societal institutions require further examination. Regarding access to education, the preliminary findings of the study indicate that just slightly more than half of the household heads (56\%) had completed primary education. Only $7.3 \%$ reported having attended tertiary education. This shows some disconnect between slum dwellers and institution of higher learning. $40.8 \%$ of the surveyed slum dwellers reported having a regular source of livelihood, an indication of some access and connections to people with resources, power and influence. The households which did not have any source of livelihood depended on well-wishers and non-governmental organisations for food and other financial support. The majority of the residents participate in local and national elections even though ethnicity and tribal inclinations often influence the participation and voting pattern. However, partnerships and networks between individuals and communities with those (individuals and institutions) with power, resources and influence need to be further explored. Moreover, other aspects of linking social capital, particularly those relating to the existence of microfinance, education, health, security, market, religious and justice institutions, merit further exploration.

\section{Implications for future research}

Based on certain attributes of bonding, bridging and linking social capital detailed in Tables 1, 2, 3 and 4 above, the IDSUE study findings indicate that some individuals in informal settlements have higher social capital than others. This highlights that quantitative indicators, where appropriately adapted to context, can provide insights into aspects of the social capital framework.
However, quantitative indicators alone are insufficient for applying the comprehensive social capital framework. Ego-centric networks ${ }^{17}$ should be investigated to determine the strength of the social ties and to determine the perceived importance of individuals in vulnerable urban settings. Such an assessment demands the deployment of methods that are more interpretive in nature. Further exploration of bridging capital in vulnerable urban contexts through socio-metric network analysis, profiling of local institutions ${ }^{18}$ and qualitative (phenomenological and ethnographic) ${ }^{19}$ studies is essential to better understanding bridging capital in slums. Similarly, there are many factors at play including the strength of linkages to socioeconomic institutions and connections of individuals with those with power, resources and influence. Therefore, mechanisms of engagement between individuals and the people with power, resources and influence need further exploration. Such exploration can take the form of aggregated survey-based responses and qualitative studies.

While an important step in contributing aggregated data concerning urban emergencies in urban settlements, future research ought to be conducted that draws on the broader social capital framework. Data availability is crucial to obtaining a full picture of social capital. The Preparedness and Resilience to address Urban Vulnerabilities project in which the authors are engaged builds on the IDSUE project and aims to collect data relating to bridging and linking capitals in addition to bonding capital that will allow for a better understanding of social capital in urban settings. It will do so by exploring the relevance of such forms of capital not only in absorbing recurrent shocks but also in adapting and transforming in response to such shocks. Comparisons of Nairobi with vulnerable settings in Bogotá and Jakarta with vastly different cultural, economic, social and political settings will be facilitated. In so doing, it is recognised that it can be challenging to collect data, for security reasons and 
because of the high turnover of populations living in such areas. Relationships with key stakeholders need to be established to ensure access to the informal settlements. Once partners rooted in the informal settlements have been identified and engaged, seminars ought to be conducted concerning how the indicators from the IDSUE project can be adapted. In applying the social capital framework, the project has served to highlight the importance of adapting indicators according to the context to measure the same attributes. The project has also served to highlight that exploring social capital in vulnerable urban settings requires a holistic approach and the use of a mixed methods approach as well as the establishment of relationships with key local stakeholders.

\section{Conclusion}

Understanding social capital (bonding, bridging and linking capitals) is the key to understanding the value of social interaction for effective localisation of humanitarian response in vulnerable urban contexts. However, what constitutes such capitals and how they can be measured need to be understood based on context-specific issues and indicators. This article has developed and provided the understanding of the attributes of the social capital concept, giving rise to a multilevel and multidimensional framework that ought to be adapted to vulnerable urban contexts. In particular, the indicators for the measurement of bonds, bridges and linkages need to be adapted to each context in which social capital is to be measured. In line with the concept analysis approach, further most likely and least likely cases of social capital in humanitarian action, particularly in urban areas, ought to be studied to clarify the concept and its relevance to humanitarian action further.

\section{Endnotes}

${ }^{1}$ Urban resilience in this paper is understood as referring to 'the ability of an urban system-and all its constituent socio-ecological and socio-technical networks across temporal and spatial scales-to maintain or rapidly return to desired functions in the face of a disturbance, to adapt to change and to quickly transform systems that limit current or future adaptive capacity' (Meerow et al. 2016, p.45). Resilience is a measure of households', communities' and societies' ability to both address their vulnerabilities by improving their capacitiesto absorb and adapt to existing and anticipated shocks and stresses while strengthening their capacities to transform/overcome to a level where these stresses are no longer relevant. Resilience is to be considered a concept that is 'co-created' by all actors in the research process, both researchers and participants.

${ }^{2}$ Gibbons et al. (2017) argues that localising humanitarian response demands that humanitarian action should always endeavour to build on the capacities and abilities of affected populations to provide assistance and protection to vulnerable populations in their own communities and societies. With the recognition that its action is subsidiary to the people, it purports to support and not simply a tool of aid donors (page 10).

${ }^{3}$ Urban is defined in relation to the capacities and vulnerabilities arising from the interdependencies that characterise highly complex and interlinking social, protection, legal, security and health systems. Urban areas feature high population density, diverse livelihoods and means of production and are often sites of governmentprovided facilities/infrastructure.

${ }^{4}$ Social network is an 'enumeration of the relationships that exist between groups of individuals or organizations (i.e. who knows whom). The structure of these networks and the character of these links between those individuals (or nodes), influence such things as how effectively the network can produce various results, its vulnerability, whether the network is well integrated or balkanized'. (Harvard Kennedy School, Harvard University).

${ }^{5}$ For more detailed discussion, see among others, Grund (2014) and Eom and Jo (2014).

${ }^{6}$ On this point, see Watts (1999) and Granovetter (1973a, b).

${ }^{7}$ Vertical and horizontal terms are used in the sense to describe and distinguish institutions and associations based on motivations that led to their formation and their functions. Governmental/non-governmental initiated macro institutions are in some studies referred to as vertical and locally initiated, informal associations as horizontal. For further description, see Grootaert and Bastelaer (2001).

${ }^{8} \mathrm{~A}$ salient example is a study done by Gallaher et al. (2013) which examined the relationship among urban agriculture, social capital and food security in Kibera slum of Nairobi Kenya. The study findings indicate that sack gardening increases social capital. However, it does not specify the form of social capital which is mainly increased that is whether bonding, bridging or linking capital. Their measurement for social capital focused on the exchange of goods and quality of relationships which according to us, such dimensions are for bonding capital.

${ }^{9}$ More details can be found in the working papers of the World Bank Social Capital Initiative.

${ }^{10}$ Organisation for Economic Co-operation and Development (OECD) Economic and Well-being study

${ }^{11}$ IDSUE study was funded by United States Agency for International Development's (USAID) Office of U.S Foreign Disaster Assistance (OFDA). The African Population and Health Research Center (APHRC) in partnership with Concern Worldwide implemented the study with the aim of developing early warning indicators to 
identify slow-onset humanitarian emergencies in urban slums. Several baseline surveys and rounds of surveillance were conducted in the informal settlements in Nairobi (Kibera, Eastleigh, Kawangware, Viwandani and Mukuru) in partnership with Kenya Red Cross Society (KRCS) and World Vision Kenya (WVK) in informal settlements in Mombasa (Bangladesh and Moroto). For more details on the urban surveillance study, see Concern Worldwide-Indicator Development for Surveillance of Urban Emergencies-IDSUE Project Research reports.

${ }^{12}$ Surveillance refers to regular monitoring of those areas/households that are particularly vulnerable to potential shocks and stresses.

${ }^{13}$ That is according to Kenya National Bureau of Statistics housing and population census report of 2009. However, other sources indicate the population may vary 'widely from 500,000 to 1,000,000'. See for example Erulkar and Matheka (2007a, b) and Mutisya and Yarime (2011a, b).

${ }^{14}$ UN-Habitat (2016) and World Cities Report (2016)

${ }^{15} \mathrm{UNHCR}$ obtained the population size from the Eastleigh local administrative authorities. However, other sources indicate the population of Eastleigh may be over 350,000 at that time (see for example Asoka et al. 2013).

${ }^{16}$ The data findings also indicate that in most cases (more than 85\%), the breadwinner is also the head of the household.

${ }^{17}$ The social network analysis (SNA) is intended to elicit the networks and contacts that are deemed essential in the locality for the slum and informal settlement dwellers to address vulnerabilities and enhance their resilience. The SNA tool questions focus on personal networks and group networks referred to as ego-centric networks and socio-metric networks respectively. Indepth interviews with residents can be conducted in each locality of the selected testbeds. Key or influential people could be identified through consultation with the principal local stakeholders involved in various programme and projects. The questions regarding the organisation influence net-map should not be intended to rank the organisations working in the area but to highlight to organisations that have influence when it comes to addressing urban vulnerabilities thereby helping the residents to be aware of which organisations to contact in times of need.

${ }^{18}$ The overall objective of the institutional profile is to delineate the relationships and networks that exist among formal and informal institutions operating in the locality, as a measure of bridging social capital. Specifically, the profile assesses the organisations' origins and development (historical and locality context, longevity and sustainability), quality of membership (reasons people join, degree of inclusiveness of the organisation), institutional capacity (quality of leadership, participation, organisational culture and organisational capacity) and institutional linkages. Between three and six institutions per locality can be profiled. For more on institutional profiles, see Krishna and Shrader (1999).

${ }^{19}$ Qualitative semi-structured questions can be asked during the focus groups and during the key informant's interviews to get rich data on bonding capital. Issues explored can be mainly on norms of trust (particularised, generalised and strategic trust), norms of reciprocity (receiving and giving help in kind) and network support among others. Regarding bridging capital, question to be asked could be around collective actions, civic engagement, association membership and participation among other attributes of bridging social capital. Likewise, issues of interest for linking capital could be mainly on individual and collective access to opportunities, individual and collective connections to people with power, resources and influence.

\section{Abbreviations}

CCCM: Camp Coordination and Camp Management; IDMC: The Internal Displacement Monitoring Centre; IDSUE: Indicator Development for the Surveillance of Urban Emergencies; NRC: Norwegian Refugee Council; UNISDR: United Nations Office for Disaster Risk Reduction; USAID: United States Agency for International Development; WHS: World Humanitarian Summit

Availability of data and materials

Data from the IDSUE project is in the possession of Concern Worldwide (Kenya).

\section{Funding}

This article has been written as part of the Preparedness and Resilience to address Urban Vulnerabilities (PRUV) project. The project has received funding from the European Union's Horizon 2020 research and innovation programme under the Marie Skłodowska-Curie grant agreement no. 691060.

\section{Authors' contributions}

DM conducted the literature review and developed the framework. He also developed the initial draft and made changes based on deliberations with co-authors. PG provided the outline and scope of the paper and provided considerable guidance to the lead author in developing the paper. RMD contributed to the writing of the introduction and illustrative case study sections in particular and assisted with the overall writing process. All authors read and approved the final manuscript.

Ethics approval and consent to participate

Ethical approval was obtained for this study and informed consent of participants obtained.

Consent for publication

The study respondents provided consent to use the data for publication purposes.

Competing interests

The authors declare that they have no competing interests.

\section{Publisher's Note}

Springer Nature remains neutral with regard to jurisdictional claims in published maps and institutional affiliations. 


\section{Received: 23 August 2017 Accepted: 26 February 2018} / Published online: 02 April 2018

\section{References}

Adger WN (2003) Social Capital, Collective Action, and Adaptation to Climate Change. Econ Geogr 79:387-404. https://doi.org/10.1111/j.1944-8287.2003. tb00220.x

Aldrich D (2012b) Social, not physical, infrastructure: the critical role of civil society after the 1923 Tokyo earthquake. Disasters 36(3):398-419

Aldrich DP (2012a) Social capital in post disaster recovery: towards a resilient and compassionate East Asian community. In: Sawada Y, Oum $S$ (eds) Economic and welfare impacts of disasters in East Asia and policy responses. ERIA research project report 2011-8. ERIA, Jakarta, pp 157-178

Aldrich, D.P., \& Smith, R. E. (2015). Social Capital and Resilience. World Humanitarian Summit (WHS) Policy, retrieved February 2017 from http:// works.bepress.com/daniel_aldrich/31/

Álvareza EC, Romaní JR (2017) Measuring social capital: further insight. Ganceta Sanitaria 31(1):57-61

Apraxine, P., Duquenne, A., Fetta, S. \& Helly, D. (2012). Urban violence and humanitarian challenges. European Union Institute for Security Studies and International Committee of the Red Cross Joint Report EUISS-ICRC Colloquium, Brussels, 19 January 2012 (Paris, Institute for Security Studies)

Asoka WN, Thuo A, Martin B (2013) Effects of Population Growth on Urban Infrastructure and Services: A Case of Eastleigh Neighborhood Nairobi, Kenya. J Anthropol Archaeology 1:41-56

Babcicky P, Seebauer S (2016) The two faces of social capital in private flood mitigation: opposing effects on risk perception, self-efficacy and coping capacity. J Risk Res. https://doi.org/10.1080/13669877.2016.1147489

Béné C, Al-Hassan RM, Amarasinghe O, Fong P, Ocran J, Onumah E et al (2016) Is resilience socially constructed? Empirical evidence from Fiji, Ghana, Sri Lanka, and Vietnam. Glob Environ Chang 38:153-170

Béné C, Frankenberger T, Nelson S (2015) Design, monitoring, and evaluation of resilience interventions: conceptual and empirical considerations, IDS working paper 459. Institute of Development Studies, Brighton

Béné C, Godfrey-Wood R, Newsham A, Davies M (2012) Resilience: new utopia or new tyranny? - reflection about the potentials and limits of the concept of resilience about vulnerability reduction programmes. In: IDS working Paper 405. Institute of Development Studies, Brighton

Bourdieu, P. (1986). In J. G. Richardson, \& C. T. Westport (Eds.) Forms of capital in Handbook of theory for the sociology of education (pp. 241-258). Greenwood Press

Chamlee-Wright E, Storr VH (2010) Expectations of government's response to disaster. Public Choice 144(1-2):253-274

Coleman J (1990) Foundations of social theory. Harvard University Press, Cambridge

Coleman J, Katz E, Menzel H (1957) The diffusion of innovation among physicians. Sociometry 20(4):253-720

Concern Worldwide \& USAID (2014) Indicator development for surveillance of urban emergencies-IDSUE. Year 4 annual research report. Concern Worldwide, Dublin

Cook KS (2001) Trust in Society. In: Russell Sage Foundation

Dasgupta P, Ismail S (eds) (1999) Social capital: a multifaceted perspective. World Bank, Washington D C

Drew, A., Kriz, A., Keating, B, \& Rowley, R. (2012). Beyond cronyism: in pursuit of deep trust. Cass Knowledge, retrieved from http://www.cassknowledge.com/

Eom Y, Jo H (2014) Generalized friendship paradox in complex networks: the case of scientific collaboration. Sci Rep 4(4603):1-6

Erulkar AS, Matheka JK (2007a) Adolescence in the Kibera Slums of Nairobi, Kenya. Population Council, New York

Erulkar AS, Matheka JK (2007b) Adolescence in the Kibera Slums of Nairobi, Kenya. Population Council, New York

Fay M (ed) (2005) The urban poor in Latin America. Directions in development. World Bank, Washington, DC

Freeman LC (2004) The development of social network analysis: a study in the sociology of science. Empirical Press, Vancouver

Gallaher CM, Kerr JM, Njenga M, Karanja NK, WinklerPrins AM (2013) Urban agriculture, social capital, and food security in the Kibera slums of Nairobi, Kenya. Agric Hum Values 30(3):389-404
Gibbons P (2017) Humanitarian concept analysis. [Lecture notes-issues and strategies of transition intervention module]. University College Dublin, Dublin

Gibbons P, McDermott R, Maitra S, Herman J (2017) Building on the capacities of crisis-affected populations: from victims to actors. Dev Policy Rev:1467-7679. https://doi.org/10.1111/dpr.12239

Gingerich, T. R., \& Cohen, M. J. (2015). Turning the humanitarian system on its head: saving lives and livelihoods by strengthening local capacity and shifting leadership to local actors. OXFAM America, retrieved from https:// www.oxfam.org/sites/www.oxfam.org/files/file_attachments/rr-turninghumanitarian-system-local-capacity-270715-en.pdf

Global CCCM Cluster (2014). Desk review: urban displacement and outside of camp. Retrieved from https://www.dropbox.com/s/p32dsdnl9e9gb9g/ UDOC\%20Desk\%20Review_Digital\%20publishing.pdf?dl=0

Granovetter M (1973a) The Strength of Weak Ties. Am J Sociol 78(6):1360-1380 doi.org/10.1086/225469

Granovetter MS(1973b) The strength of weak Ties

Grootaert, C. (1999) Social capital, household welfare, and poverty in Indonesia. World Bank policy research working paper no. 2148. Retrieved from https:// ssrn.com/abstract $=569207$

Grootaert C, Bastelaer T (2001) Understanding and measuring social capital: a synthesis of findings and recommendation from the social capital initiative. Working paper no. 24. World Bank, Washington D.C

Grund T (2014) Why your friends are more important and special than you think. Sociol Sci 1:128-140

Hardin R (2002) Trust and trustworthiness. Russell Sage, New York

Hawkins RL, Maurer K (2010) Bonding, bridging and linking: how social capital operated in New Orleans following Hurricane Katrina. Bri J Soc Work 40: $1777-1793$

IDMC, and NRC (2014) Internal displacement monitoring centre and Norwegian refugee council report, global estimate 2014. People Displaced by Disasters, Geneva

IFRC (2016) World disasters report 2016: resilience: saving lives today, investing for tomorrow. IFRC, Geneva

Jackson J, Bradford B, Hough M, Kuha J, Stares S, Widdop S, Galev T (2011) Developing European indicators of trust in justice. Eur J Criminol 8(4):267-285

Keeley B (2007) Human capital how what you know shapes your life. OECD Insights, OECD Publishing, Paris

Klinenberg E (2002) Heat Wave: A Social Autopsy of Disaster in Chicago. University of Chicago Press, Chicago

Knox-Clarke P, Ramalingam B (2012) Meeting the urban challenge: adapting humanitarian efforts to an urban world. ALNAP meeting paper. ALNAP/ODI, London

Kramer RM, Tyler TR (eds) (1996) Trust in organizations: frontiers of theory and research. Sage Publications, Thousand Oaks

Kreuter MW, Lezin N (2002) Social capital theory: implications for communitybased health promotion. In: DiClemente RJ, Crosby RA, Kegler MC (eds) Emerging theories in health promotion practice and research. Jossey-Bass, New York

Krishna A, Shrader E (1999) Social capital assessment tool. Paper prepared for the conference on social capital and poverty reduction. The World Bank, Washington D.C. June 22-24

Krishna A, Shrader E (2000) Cross-cultural measures of social capital: a tool and results from India and Panama. Social capital initiative working paper no. 21. World Bank, Washington D.C

Lall SV, Deichmann U (2012) Density and disasters: economics of urban hazard risk. World Bank Research Observer, World Bank Group 27(1):74-105

Ledogar RJ, Fleming J (2008) Social capital and resilience: a review of concepts and selected literature relevant to aboriginal youth resilience research. Pimatisiwin 6(2):25-46

Lin N (1999a) Building a network theory of social capital. Connect 22(1):28-51 Lin N (1999b) Social networks and status attainment. Annu Rev Sociol 25:467-487

Lofors J, Sundquist K (2007) Low-linking social capital as a predictor of mental disorders: a cohort study of 4.5 million Swedes. Soc Sci Med 64(1):21-34

Manzano Nunez R (2016) Linking social capital: a forgotten component of social capital. J Epidemiol Community Health 70(5):526. https://doi.org/10.1136/ jech-2015-207100

Meerow S, Newell JP, Stults M (2016) Defining urban resilience: a review. Landsc Urban Plan 147(2016):38-49

Mitchell A (2013) Risk and resilience: from good idea to good practice. OECD development co-operation working paper. The development assistance 
committee: enabling effective development a scoping study for the experts group on risk and resilience. OECD, Paris

Murshed, Z., (2015). United Nation Development Programme. Retrieved January 12, 2016, from http://www.undp.org/content/undp/en/home/blog/2015/1/ 29/Bigger-cities-don-t-have-to-mean-bigger-risks.html

Musinguzi LK, Turinawe EB, Rwemisisi JT, de Vries DH, Mafigiri DK, Muhangi D et al (2017) Linking communities to formal health care providers through village health teams in rural Uganda: lessons from linking social capital. Hum Resour Health 15:4 https://doi.org/10.1186/s12960-016-0177-9

Mutisya E, Yarime M (2011a) Understanding the grassroots dynamics of slums in Nairobi: the dilemma of Kibera informal settlements. International Transaction Journal of Engineering, Management, \& Applied Sciences \& Technologies 2(2):197-213

Mutisya E, Yarime M (2011b) Understanding the Grassroots Dynamics of Slums in Nairobi: The Dilemma of Kibera Informal Settlements. Int Trans J Eng Manage Appl Sci Technol 2(2):197-213

Narayan D (1999) Bonds and bridges: social capital and poverty. Policy research working paper 2167. Poverty reduction and economic management network. World Bank, Washington, D.C.

Nooteboom B (2002) Trust: forms, foundations, functions, failures and figures. Elgar, Cheltenham

North D (1990) A transaction cost theory of politics. J Theor Polit 2(4):355-367

North D (1992) Institutions and economic theory. Am Econ 36(1):3-6 Retrieved from http://www.jstor.org/stable/25603904

Nuopponen A (2010) Methods of concept analysis - a comparative study. LSP Journal 1(1) Retrieved from http://Isp.cbs.dk

Paliszkiewicz JO (2011) Trust management: literature review. Management 6(4): 315-331

Pantuliano S, Metcalfe V, Haysom S, Davey E (2012) Urban vulnerability and displacement: a review of current issues. Disasters 36:s1

Parker E, Maynard V (2015) Humanitarian response to urban crises: a review of area-based approaches. IIED working paper. London, IIED

Pavanello, S. (2012). Rethinking the humanitarian response: emerging approaches for engagement in urban crises. ATHA, retrieved from http://www.alnap.org/ resource/20067.aspx

Pfefferbaum, B., Van Horn, R.L., \& Pfefferbaum, R.L., (2015). A conceptual framework to enhance community resilience using social capital. Clin Soc Work Journal, Springer Published Online

Portes A (1998) Social capital: its origins and applications in modern sociology. Annu Rev Sociol 24:1-24

Portes A (2014) Downsides of social capital. Proc Natl Acad Sci 111(52):1840718408

Putnam RD (1993) Making democracy work—civic traditions in modern Italy. Princeton University Press, Princeton

Putnam RD (2000) Bowling alone: the collapse and revival of American community. Simon \& Schuster, London

Reinhardt GY (2015) Race, trust, and return migration - the political drivers of post-disaster resettlement. Polit Res Q 68(2):350-362

Rice E, Yoshioka-Maxwell A (2015) Social network analysis as a toolkit for the science of social work. J Soc Soc Work Res 6(3):369-383

Roberts BR (1973) Organizing Strangers. University of Texas Press, Austin

Sako M (1992) Prices, quality, and trust: inter-firm relations in Britain and Japan. Cambridge University Press, Cambridge

Scrivens, K., \& Smith C. (2013). Four interpretations of social capital: an agenda for measurement. OECD Statistics Working Papers, 2013/06, OECD Publishing

Shaw R, Goda K (2004) From disaster to sustainable civil society: the Kobe experience. Disasters 28(1):16-40

Siegler V (2014) Measuring social capital. Office for National Statistics, London

Siegler V (2015) Measuring social capital. Office for National Statistics, London

Smith SS (2010) Race and trust. Annu Rev Sociol 36:453-475

Stone W (2001) Measuring social capital: towards a theoretically informed measurement framework for researching social capital in family and community life. Australian Institute of Family Studies, Melbourne Research Paper 24

Story, W. (2013). Social capital and health in the least developed countries: a critical review of the literature and implications for a future research agenda, Global

Sundquist K, Hamanoc T, Kawakami N, Shiwaku K, Sundquist J (2014) Linking social capital and mortality in the elderly: a Swedish national cohort study. Exp Gerontol 55(2014):29-36

Titeca K, Vervisch T (2008) The dynamics of social capital and community associations in Uganda: linking capital and its consequences. World Dev 36(11):2205-2222
UN General Assembly, (2016). One humanity: shared responsibility: report of the Secretary-General for the World Humanitarian Summit, UN Doc. A/70/709, 2nd February 2016

UN-Habitat (2009) Planning sustainable cities. United Nations, Nairobi

UN-Habitat, (2016). UN-Habitat III, adoption of the final outcome of the conference, Quito, 17-20 October 2016, A/CONF.226/4

UNISDR (2014) Progress and challenges in disaster risk reduction: a contribution towards the development of policy indicators for the post-2015 framework on disaster risk reduction. The United Nations Office for Disaster Risk Reduction, Geneva

Walker L, Avant K (1995) Strategies for theory construction in nursing, 3rd edn. Appleton-Century-Crofts, Norwalk

Walker L, Avant K (2005) Strategies for theory construction in nursing, 4th edn. Prentice Hall, New Jersey

Walker LO, Avant KC (2011) Concept analysis. In: Walker LO, Avant KC (eds) Strategies for theory construction in nursing, 5th edn. Pearson Prentice Hall, Upper Saddle River, pp 157-179

Wall, I., \& Hedlund, K. (2016). Localisation and locally-led crisis response: a literature review. Local to Global Protection (L2GB). Swiss Agency for Development and Cooperation

Wasserman S, Faust K (1994) Social network analysis: methods and applications Cambridge University Press, Cambridge

Watts DJ (1999) Networks, Dynamics, and the Small-World Phenomenon. Am J Sociol 105(2):493-527. https://doi.org/10.1086/210318

Woolcock M (1998) Social capital and economic development: toward a theoretical synthesis and policy framework. Theory Soc 27(2):151-208

Woolcock M (2005) Calling on friends and relatives: social capital. In: Fay M (ed) The urban poor in Latin America. Directions in development. World Bank, Washington, DC, pp 219-238

Woolcock M, Narayan D (2000) Social capital: its implications for development theory, research and policy. World Bank Res Obs 15(2):225-249

World Bank (2003) Poverty in Guatemala. Report No. 24221-GU. World Bank, Latin America and Caribbean Region, Washington, DC

World Cities Report (2016) Urbanization and Development: Emerging Futures. Nairobi, United Nations Human Settlement Programme

World Humanitarian Summit Secretariat (2015) Restoring humanity: global voices calling for action: synthesis of the consultation process for the world humanitarian summit. United Nations, New York

\section{Submit your manuscript to a SpringerOpen ${ }^{\circ}$ journal and benefit from:}

- Convenient online submission

- Rigorous peer review

- Open access: articles freely available online

- High visibility within the field

- Retaining the copyright to your article

Submit your next manuscript at springeropen.com 